\title{
Characterization of the geomechanical properties of Oligocene clay in Budapest
}

\author{
Ildikó Barsi
}

Department of Construction Materials and Engineering Geology

Budapest University of Technology and Economics, Budapest

\begin{abstract}
The Oligocene Kiscell Clay is a widespread sediment of the Budapest region. The best-evaluated parts of the deposit are found along the new Metro (subway) line (Line 4) on the Buda side of the Danube River, where cores were cut. The geomechanical parameters of the Kiscell Clay were studied and evaluated using 481 samples from 41 cores. Nearly 5000 data were processed using different statistical parameters. The results of the statistical analyses are compared with previously-described soil-mechanical parameters; regional correlations of the mechanical properties of the Kiscell Clay are made by comparison with the results of previous analyses (Görög 2007a). There are significant discrepancies in the datasets of cohesion and uniaxial compressive strength, but other parameters show better correlation. In any case these analyses provide information for the engineering geologic design and planning for underground structures.
\end{abstract}

Keywords: liquid limit, cohesion, plasticity index, density, Kiscell clay

\section{Introduction}

At present mathematical statistics play an important role in geotechnical engineering. The availability of a large dataset permits the evaluation of the physical parameters of different geologic units, which may help in later analysis. Geostatistical investigations of different rock types, such as the Buda Marl (Görög 2007b), granite (Barsi et al. 2012), travertine (Török and Vásárhelyi 2010), or porous limestone (Kárpátiné and Török 2007) exist. The Kiscell Clay is the most frequently-occurring and investigated rock type of Budapest (Barsi et al. 2012; Görög 2007a; Paál, 1975; Horváth and Móczár 2011); therefore a significant

Address: I. Barsi: H-1111 Budapest, Műegyetem rkp. 3. Hungary, e-mail: ildiko.barsi@gmail.com Received: June 27, 2012; accepted: November 28, 2012 
amount of data is available. The new Metro Line 4 in the Buda area was mainly tunneled through the Kiscell Clay. For the purpose of investigation and design several corings were carried out to recover subsurface occurrences of this strongly compacted clay. For the present paper the data from 41 corings were evaluated and the results compared with previous investigations of the physical properties of the Kiscell Clay (Paál 1975; Görög 2007a).

\section{The Kiscell Clay}

The Kiscell Clay can be divided into several petrographically different units. One variety of the Kiscell Clay is a plastic, non-compacted sediment. For the analysis of this type soil-mechanical methods can be used. However, in many cases the clay is found in a well-cemented rock-like form, due to the thick overburden and diagenetic processes. At greater depth (min. 20-30 meters) it is much harder and more strongly consolidated.

The corings carried out along Metro Line 4 were divided into three zones by RQD values. The upper zone is weathered, and includes the upper, yellow, weathered part and grey, broken part of the Kiscell Clay. The second is the expanded and cracked zone which lies 10-20 meters below the surface (Fig. 1). Finally, the lowest zone is beyond the clay expansion boundary, where the behavior of sediment is similar to that of a rock (Horváth et al. 2000).

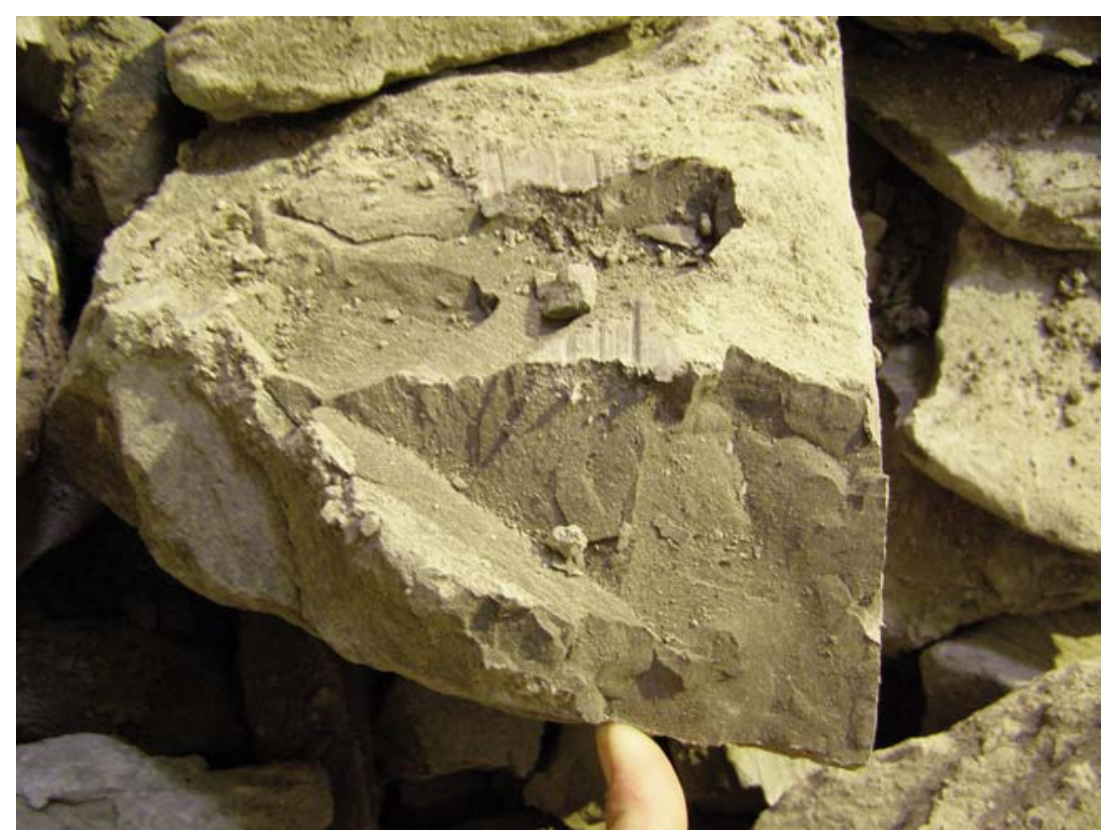

Fig. 1

Kiscell Clay from an excavation pit from the Metro Line 4 


\section{Dataset}

In the past decades a large number of cores were cut in connection with the design of the new Metro (subway) line (Line 4); these play an important role in our understanding of the engineering geology of Budapest. Forty-one cores from the period 1977-2008 were chosen for the geotechnical parameter analyses of the Kiscell Clay (Fig. 2). In all 481 samples and 4676 data values were analyzed.

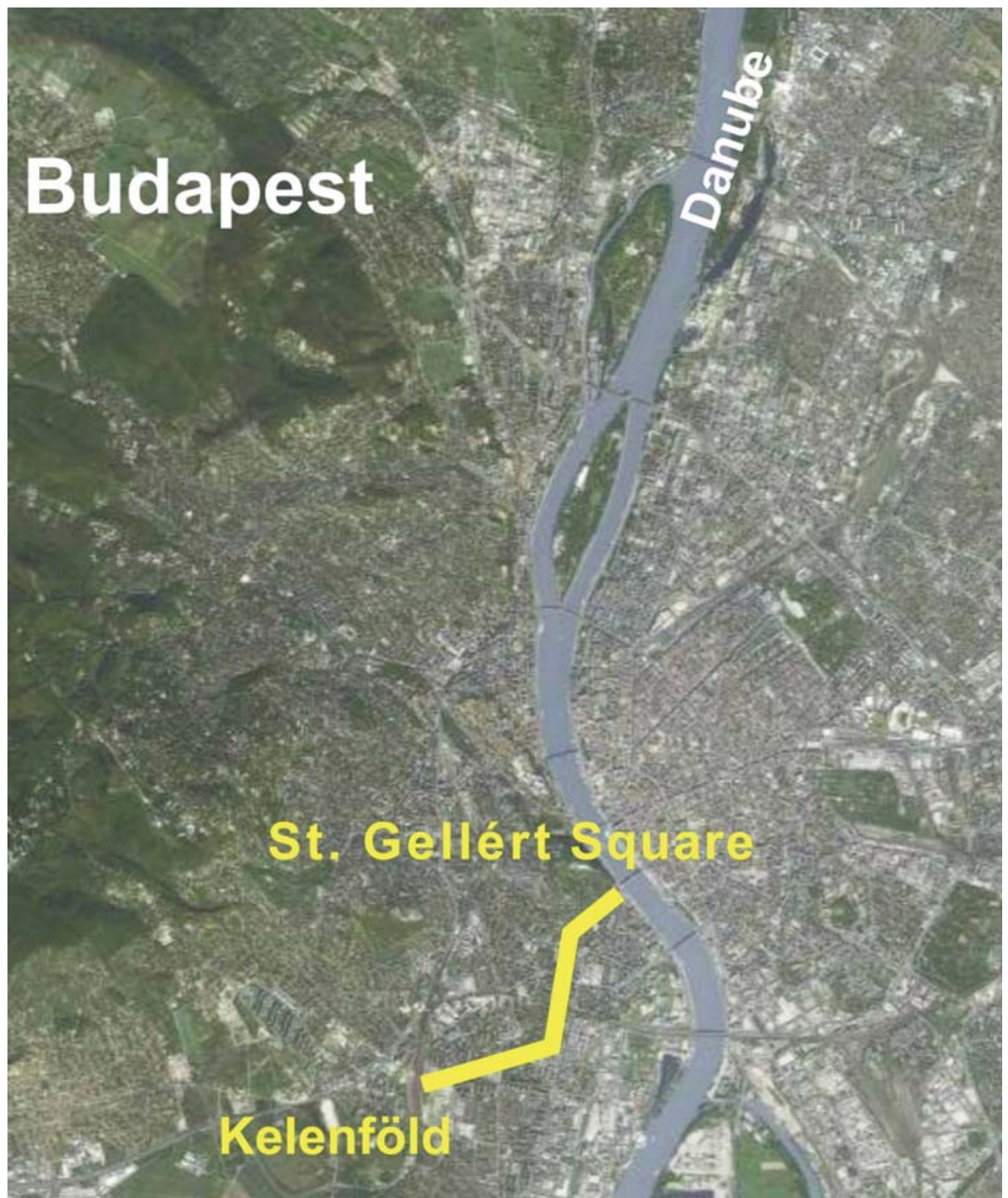

Fig. 2

Analyzed area of Group 1 
Hereafter this data set will be called the dataset of Group 1. The studied parameters were: water content, liquid limit, plasticity limit, plasticity index, consistency index, void ratio, wet density, dry density, water-saturated density, degree of saturation, angle of friction, cohesion, modulus of elasticity, coefficient of compressibility, and uniaxial compressive strength.

Previously Paál (1974, 1975) and Görög (2007a) analyzed the soil physical parameters of the Kiscell Clay with statistical methods. Görög (2007a) processed 1242 values of gray Kiscell Clay from Lágymányos, Budaörs, Rózsadomb and Óbuda (Fig. 4). The results of this study (hereafter referred to as Group 2) includes all necessary characteristic parameters. Paál $(1974,1975)$ evaluated 2536 values from 483 samples from Kelenföld, Rózsadomb and the Óbuda area (Fig. 3). This dataset (hereafter called Group 3) was obtained from the period 1955 to 1975 and although this analysis does not contain every parameter, the available data set does permit comparison. The studied properties of previous work (datasets 2 and 3) and of the present paper (dataset 1) are summarized in Table 1.

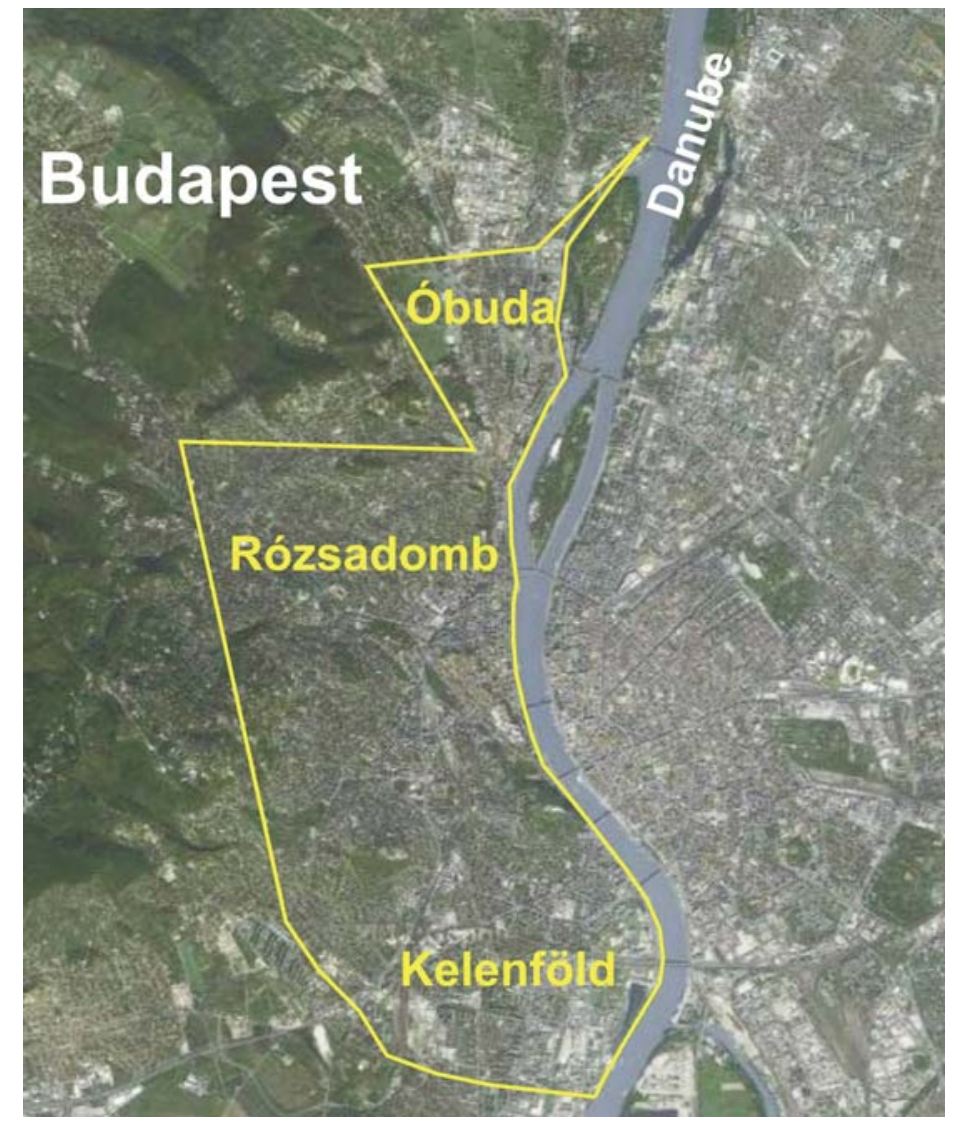

Fig. 3

Analyzed area of Group 3 
Fig. 4

Analyzed area of Group 2

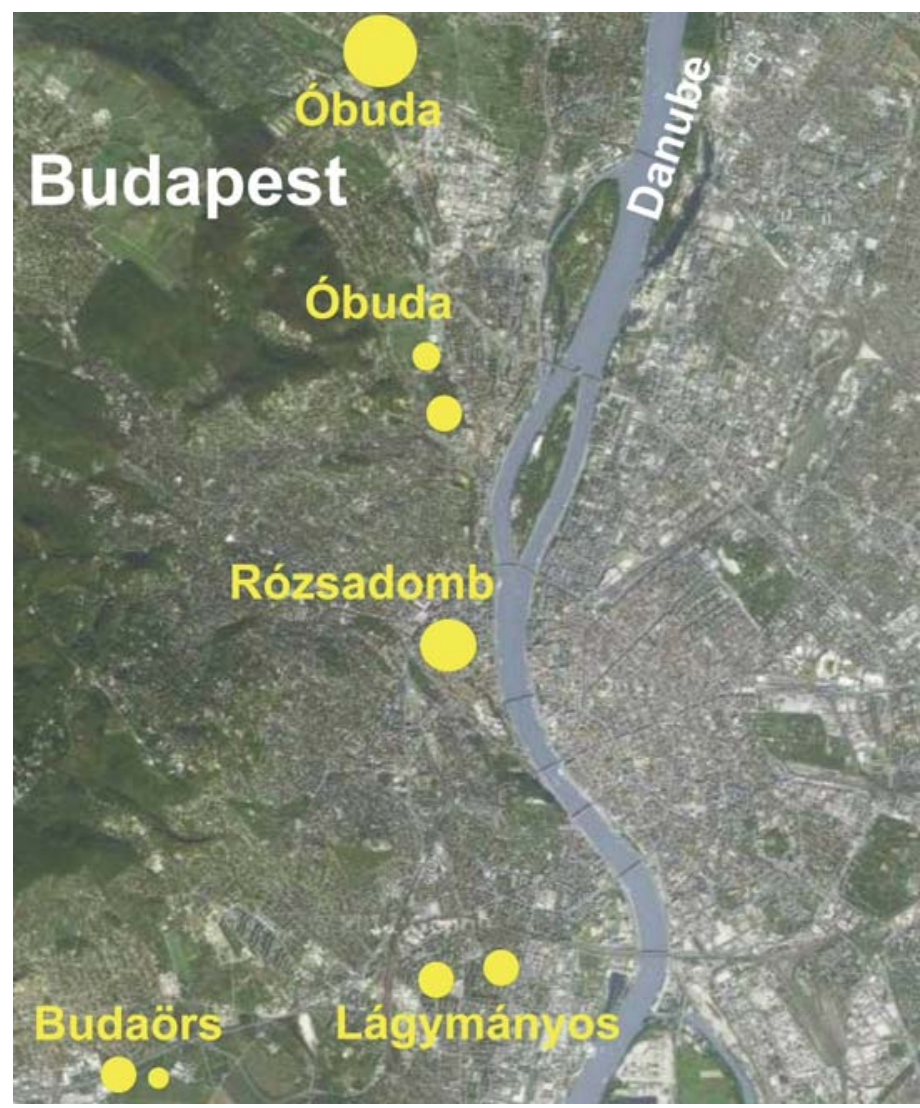

Table 1

Data properties of the groups

\begin{tabular}{|c|c|c|c|c|}
\hline Group no. & Geographic location & \multirow{3}{*}{\begin{tabular}{l}
\multicolumn{1}{c}{ Analysed parameters } \\
water content, liquid limit, \\
plasticity limit, plasticity \\
index, consistency index, \\
void ratio, wet density, dry \\
density, water-saturated \\
density, degree of saturation, \\
angle of friction, cohesion, \\
modulus of elasticity, \\
coefficient of \\
compressibility, uniaxial \\
compressive strength
\end{tabular}} & No. of data & Source \\
\hline Group 1 & $\begin{array}{l}\text { Trace of Metro line } 4 \\
\text { at Buda side }\end{array}$ & & 4676 & $\begin{array}{l}\text { present } \\
\text { paper }\end{array}$ \\
\hline Group 2 & $\begin{array}{l}\text { Lágymányos, Budaörs, } \\
\text { Rózsadomb, Óbuda }\end{array}$ & & 1242 & $\begin{array}{l}\text { Görög } \\
2007 \mathrm{a}\end{array}$ \\
\hline Group 3 & $\begin{array}{c}\text { Kelenföld, } \\
\text { Rózsadomb, Óbuda }\end{array}$ & $\begin{array}{l}\text { liquid limit, plasticity index, } \\
\text { consistency index, wet } \\
\text { density, angle of friction, } \\
\text { cohesion, coefficient of } \\
\text { compressibility }\end{array}$ & 2536 & $\begin{array}{c}\text { Paál 1974, } \\
1975\end{array}$ \\
\hline
\end{tabular}




\section{Geomechanical parameters}

The large amount of data available was studied by applying descriptive statistics. The statistical characteristics of soil mechanics variables of the different datasets - such as mean, median, range, standard deviation, coefficient of variation, skewness - are discussed here one by one.

\section{Water content}

By using the data set of Görög (2007a) (Group 2) it is possible to compare the water content of the two different groups. Along Metro Line 4 (Group 1) the water content values show less of a range; the average values are also smaller, with mean of $13.0 \%$ and median of $13.0 \%$, in contrast to $16.0 \%$ in Group 2 (Görög 2007a). The distributions of the two sample groups are different by skewness and kurtosis as well. The samples of Group 2 have higher kurtosis values than those of Group 1, while the latter has a flatter histogram relative to a normal distribution. Both datasets have positive skewness; thus lower values prevail (Table 2).

Table 2

Statistical characteristics of water content

\begin{tabular}{|l|c|c|c|c|c|}
\hline \multicolumn{7}{|c|}{ Water content, $\boldsymbol{w}$ [\%] } \\
\hline & $\begin{array}{c}\text { No. of } \\
\text { sample }\end{array}$ & Minimum & Maximum & Mean & Median \\
\hline Group 1 & 454 & 4.0 & 23.0 & 13.0 & 13.0 \\
\hline Group 2 & 144 & 1.4 & 27.6 & 16.6 & 16.0 \\
\hline & Range & $\begin{array}{c}\text { Standard } \\
\text { deviation }\end{array}$ & $\begin{array}{c}\text { Coefficient } \\
\text { of variation }\end{array}$ & Skewness & Kurtosis \\
\hline Group 1 & 19.0 & 3.4 & 0.26 & 0.22 & -0.26 \\
\hline Group 2 & 26.2 & 4.3 & 0.26 & 0.35 & 0.63 \\
\hline
\end{tabular}

\section{Liquid limit}

Data were available for all three groups in terms of liquid limit. In Group 1 the range of liquid limit is the largest $(57.9 \%)$, while values of the other two groups are smaller: 36.7 for Group 2 and $25.0 \%$ for Group 3. However, medians and means do not differ significantly. The distribution of datasets of Group 2 have a lesser range and a sharper peak in contrast to Group 1, which has a high, positive skewness. Medians are very similar for all three groups (Table 3). 
Table 3

Statistical characteristics of liquid limit

\begin{tabular}{|l|c|c|c|c|c|}
\hline & $\begin{array}{c}\text { No. of } \\
\text { sample }\end{array}$ & Minimum & Maximum & Mean & Median \\
\hline Group 1 & 467 & 27.7 & 85.6 & 54.4 & 53.2 \\
\hline Group 2 & 134 & 33.0 & 69.7 & 52.6 & 53.1 \\
\hline Group 3 & 444 & 42.0 & 67.0 & 54.7 & 54.7 \\
\hline & Range & $\begin{array}{c}\text { Standard } \\
\text { deviation }\end{array}$ & $\begin{array}{c}\text { Coefficient of } \\
\text { variation }\end{array}$ & Skewness & Kurtosis \\
\hline Group 1 & 57.9 & 11.5 & 0.21 & 0.59 & -0.02 \\
\hline Group 2 & 36.7 & 6.9 & 0.13 & -0.16 & 0.32 \\
\hline Group 3 & 25.0 & 7.20 & 0.13 & & \\
\hline
\end{tabular}

\section{Plasticity index}

The statistical parameters of the plasticity index show a similar trend those of liquid limit. Values cover a wide range in Group 1, even though medians of the three groups are very similar: around $30.0 \%$. Consequently half of the samples represent fat clay in every group. Group 1 has the largest standard deviation and significant positive skewness. Lower range and higher kurtosis are typical feature of Group 2 (Table 4).

Table 4

Statistical characteristics of the plasticity index

\begin{tabular}{|l|c|c|c|c|c|}
\hline & $\begin{array}{c}\text { No. of } \\
\text { sample }\end{array}$ & Minimum & Maximum & Mean & Median \\
\hline Group 1 & 475 & 10.7 & 66.6 & 32.3 & 30.2 \\
\hline Group 2 & 134 & 16.0 & 47.0 & 29.5 & 30.0 \\
\hline Group 3 & 444 & 18.0 & 39.0 & 29.1 & 29.1 \\
\hline & Range & $\begin{array}{c}\text { Standard } \\
\text { deviation }\end{array}$ & $\begin{array}{c}\text { Coefficient of } \\
\text { variation }\end{array}$ & Skewness & Kurtosis \\
\hline Group 1 & 55.9 & 11.1 & 0.34 & 0.84 & 0.37 \\
\hline Group 2 & 31.0 & 5.7 & 0.19 & 0.17 & 0.61 \\
\hline Group 3 & 21.0 & 6.20 & 0.21 & & \\
\hline
\end{tabular}




\section{Consistency index}

Medians of consistency index cover a very small range, with values between 1.24 and 1.29. Standard deviations are also similar, with small differences (0.16-0.19). The samples from Groups 1 and 3 were defined as a hard clay, but values of Group 2 belong to the stiff or hard category. The diagenesis and the overcompacted nature of the Kiscell Clay could explain this. Group 1 shows large kurtosis and skewness; this is explained by the fact that the maximum value is 2.00 but only $9 \%$ of the consistency index data is above 1.60 (Table 5).

Table 5

Statistical characteristics of consistency index

\begin{tabular}{|l|c|c|c|c|c|}
\hline \multicolumn{7}{|c|}{ Consistency index, I $_{\boldsymbol{c}}$ [-] } \\
\hline & $\begin{array}{c}\text { No. of } \\
\text { sample }\end{array}$ & Minimum & Maximum & Mean & Median \\
\hline Group 1 & 451 & 1.00 & 2.00 & 1.32 & 1.29 \\
\hline Group 2 & 132 & 0.75 & 1.65 & 1.22 & 1.24 \\
\hline Group 3 & 443 & 1.03 & 1.56 & 1.29 & 1.29 \\
\hline & Range & $\begin{array}{c}\text { Standard } \\
\text { deviation }\end{array}$ & $\begin{array}{c}\text { Coefficient } \\
\text { of variation }\end{array}$ & Skewness & Kurtosis \\
\hline Group 1 & 1.00 & 0.19 & 0.14 & 0.99 & 0.88 \\
\hline Group 2 & 0.90 & 0.17 & 0.14 & -0.35 & -0.01 \\
\hline Group 3 & 0.53 & 0.16 & 0.12 & & \\
\hline
\end{tabular}

\section{Wet density}

The average characteristics of wet density of the three analyzed groups also show only small differences $\left(2160-2261 \mathrm{~kg} / \mathrm{m}^{3}\right)$. Group 3 has the smallest values. Distributions show negative skewness; thus the greatest part of data represent higher values (Table 6). The standard deviation values of density show the smallest coefficient of variation, which means that this parameter is a representative property of the Kiscell Clay and no significant errors were made during laboratory testing of this parameter.

\section{Void ratio}

The void ratio has the largest span in terms of range, median, and mean. The median of Group 1 is 0.36 , which means that more than half of the samples are below a value of 0.40 , a typical feature of rock-like, consolidated sediments. On the contrary, all the analyzed values of Group 3 have a median higher than 0.36 (Table 7). 
Table 6

Statistical characteristics of wet density

\begin{tabular}{|c|c|c|c|c|c|}
\hline \multicolumn{6}{|c|}{ Wet density, $\rho_{w}\left[\mathrm{~kg} / \mathrm{m}^{3}\right]$} \\
\hline & $\begin{array}{l}\text { No. of } \\
\text { sample }\end{array}$ & Minimum & Maximum & Mean & Median \\
\hline Group 1 & 300 & 1960 & 2510 & 2261 & 2270 \\
\hline Group 2 & 155 & 1850 & 2470 & 2189 & 2200 \\
\hline \multirow[t]{2}{*}{ Group 3} & 482 & 1940 & 2300 & 2120 & \\
\hline & Range & $\begin{array}{l}\text { Standard } \\
\text { deviation }\end{array}$ & $\begin{array}{c}\text { Coefficient of } \\
\text { variation }\end{array}$ & Skewness & Kurtosis \\
\hline Group 1 & 550 & 123 & 0.05 & -0.43 & -0.50 \\
\hline Group 2 & 620 & 112 & 0.05 & -0.81 & 0.90 \\
\hline Group 3 & 360 & 110 & 0.05 & & \\
\hline
\end{tabular}

Table 7

Statistical characteristics of the void ratio

\begin{tabular}{|l|c|c|c|c|c|}
\hline \multicolumn{7}{|c|}{ Void ratio, e [-] } \\
\hline & $\begin{array}{c}\text { No. of } \\
\text { sample }\end{array}$ & Minimum & Maximum & Mean & Median \\
\hline Group 1 & 250 & 0.13 & 0.68 & 0.37 & 0.36 \\
\hline Group 2 & 97 & 0.30 & 0.80 & 0.46 & 0.44 \\
\hline Group 3 & 483 & 0.36 & 0.72 & 0.54 & 0.54 \\
\hline & Range & $\begin{array}{l}\text { Standard } \\
\text { deviation }\end{array}$ & $\begin{array}{c}\text { Coefficient } \\
\text { of variation }\end{array}$ & Skewness & Kurtosis \\
\hline Group 1 & 0.55 & 0.13 & 0.34 & 0.37 & -0.69 \\
\hline Group 2 & 0.50 & 0.11 & 0.24 & 1.10 & 0.81 \\
\hline Group 3 & 0.36 & 0.11 & 0.20 & & \\
\hline
\end{tabular}




\section{Cohesion}

In terms of cohesion there are big differences between the characteristics of the three studied groups. Mean values of Groups 1 and 2 are very close 232 to $\mathrm{kPa}$ and $211 \mathrm{kPa}$, respectively, but that of Group 3 is much lower $(97 \mathrm{kPa})$. The range of Group 2 is much narrower than that of Group 1, but the distribution of Group 2 is much flatter (Table 8).

Table 8

Statistical characteristics of cohesion

\begin{tabular}{|l|c|c|c|c|c|}
\hline \multicolumn{7}{|c|}{ Cohesion, $\mathbf{c}\left[\mathbf{k N} \mathbf{m}^{2}\right]$} \\
\hline & $\begin{array}{c}\text { No. of } \\
\text { sample }\end{array}$ & Minimum & Maximum & Mean & Median \\
\hline Group 1 & 149 & 4 & 630 & 232 & 240 \\
\hline Group 2 & 52 & 16 & 400 & 211 & 200 \\
\hline Group 3 & 50 & & & 97 & \\
\hline & Range & $\begin{array}{c}\text { Standard } \\
\text { deviation }\end{array}$ & $\begin{array}{c}\text { Coefficient } \\
\text { of variation }\end{array}$ & Skewness & Kurtosis \\
\hline Group 1 & 626 & 116 & 0.50 & 0.12 & -0.04 \\
\hline Group 2 & 384 & 120 & 0.57 & 0.01 & -1.26 \\
\hline Group 3 & & 49 & 0.51 & & \\
\hline
\end{tabular}

\section{Angle of friction}

Significant differences in the values angle of friction were found. For this parameter, Groups 2 and 3 show some similarities, with means of $25^{\circ}$ and $21^{\circ}$, respectively. The median of group 1 is $35^{\circ}$, which means that half of data lies between $35^{\circ}$ and $68^{\circ}$ (Table 9). This could reflect differences in the depth of samples and also some influences of weathering.

\section{Coefficient of compressibility}

The statistical analysis of coefficient of compressibility clearly showed that there were limited amounts of data for Groups 1 and 2, which resulted in high standard deviations. The values obtained for Group 3 are more reliable, with a median of 13.8 MPa (Table 10). 
Table 9

Statistical characteristics of the angle of friction

\begin{tabular}{|l|c|c|c|c|c|}
\hline \multicolumn{7}{|c|}{ Angle of friction. $\boldsymbol{\varphi}$ / $\%$ } \\
\hline & $\begin{array}{c}\text { No. of } \\
\text { sample }\end{array}$ & Minimum & Maximum & Mean & Median \\
\hline Group 1 & 144 & 4 & 68 & 36 & 35 \\
\hline Group 2 & 49 & 5 & 43 & 25 & 24 \\
\hline Group 3 & 53 & 11 & 29 & 21 & \\
\hline & Range & $\begin{array}{c}\text { Standard } \\
\text { deviation }\end{array}$ & $\begin{array}{c}\text { Coefficient } \\
\text { of variation }\end{array}$ & Skewness & Kurtosis \\
\hline Group 1 & 64 & 15 & 0.42 & 0.02 & -0.55 \\
\hline Group 2 & 38 & 11 & 0.44 & -0.03 & -0.75 \\
\hline Group 3 & 18 & 6 & 0.30 & & \\
\hline
\end{tabular}

Table 10

Statistical characteristics of the coefficient of compressibility

\begin{tabular}{|l|c|c|c|c|c|}
\hline \multicolumn{7}{|c|}{ Coefficient of compressibilitv. $\boldsymbol{E}_{\boldsymbol{S}}$ [MPaI } \\
\hline & $\begin{array}{c}\text { No. of } \\
\text { sample }\end{array}$ & Minimum & Maximum & Mean & Median \\
\hline Group 1 & 17 & 5.7 & 33.3 & 18.3 & 17.2 \\
\hline Group 2 & 20 & 8.1 & 70.0 & 15.8 & 11.9 \\
\hline Group 3 & 137 & 7.8 & 19.9 & 14.3 & 13.8 \\
\hline & Range & $\begin{array}{l}\text { Standard } \\
\text { deviation }\end{array}$ & $\begin{array}{c}\text { Coefficient } \\
\text { of variation }\end{array}$ & Skewness & Kurtosis \\
\hline Group 1 & 27.6 & 8.1 & 0.44 & 0.47 & -0.58 \\
\hline Group 2 & 61.9 & 13.8 & 0.87 & 3.59 & 13.93 \\
\hline Group 3 & 12.1 & 3.70 & 0.26 & & \\
\hline
\end{tabular}

Modulus of Elasticity

In reference to modulus of elasticity there are sufficient data from Groups 1 and 2 . The range of Group 2 is double than that of Group 1. This fact can be explained by the high maximum values of Group 2, even though their medians are similar 
(98.5-110.0 MPa). Skewness and kurtosis of distributions are very large. Kurtosis of Group 1 is more than 4 times higher than that of Group 2. The coefficients of variation are also significant. This can be explained by the smaller number of available data (Table 11).

\section{Compressive strength}

The compressive strength shows an opposite trend to that of the modulus of elasticity when the two groups ( 1 and 2$)$ are compared. The range of Group 1 is

Table 11

Statistical characteristics of coefficient of the modulus of elasticity

\begin{tabular}{|l|c|c|c|c|c|}
\hline \multicolumn{7}{|c|}{ Modulus of elasticity, E [MPa] } \\
\hline & $\begin{array}{c}\text { No. of } \\
\text { sample }\end{array}$ & Minimum & Maximum & Mean & Median \\
\hline Group 1 & 44 & 3.7 & 405 & 107.4 & 98.5 \\
\hline Group 2 & 63 & 7.5 & 827.2 & 198.5 & 110.0 \\
\hline & Range & $\begin{array}{c}\text { Standard } \\
\text { deviation }\end{array}$ & $\begin{array}{c}\text { Coefficient of } \\
\text { variation }\end{array}$ & Skewness & Kurtosis \\
\hline Group 1 & 401.3 & 81.0 & 0.75 & 1.80 & 4.50 \\
\hline Group 2 & 819.7 & 210.9 & 1.06 & 1.44 & 1.11 \\
\hline
\end{tabular}

of an almost fourfold value; median (1.76 MPa) and mean (4.87 MPa) are double the value in comparison with Group 2. Distributions show highly positive skewness; thus, lower values are dominant, and this was indicated by the position of the medians. It should be noted that there was a considerable amount of data available from these samples (especially in Group 1); thus the coefficient of variations is very high (Table 12).

\section{Results of regression analysis}

To determine the relationships between soil physical parameters of the Kiscell Clay, pairs of parameters were illustrated on scatter plots. The regression curve was fitted on these point sets using the least-squares method. Strength of relationship was characterized by Pearson's correlation coefficient (r), such as the compared previous research data (Groups 2 and 3). The results of the previous investigations also were plotted in the diagrams for ease of comparison.

First the point pairs of depth and void ratio were plotted; the best regression curve is a power function (1) with a correlation coefficient of -0.77 (Fig. 5). The regression curve in Group 2 is also a power function (2), showing a similar 
Table 12

Statistical characteristics of compressive strength

\begin{tabular}{|l|c|c|c|c|c|}
\hline \multicolumn{7}{|c|}{ Compressive strength, $\sigma_{\boldsymbol{c}}$ [MPa] } \\
\hline & $\begin{array}{c}\text { No. of } \\
\text { sample }\end{array}$ & Minimum & Maximum & Mean & Median \\
\hline Group 1 & 226 & 0.05 & 22.20 & 4.87 & 1.76 \\
\hline Group 2 & 52 & 0.07 & 6.72 & 1.89 & 0.94 \\
\hline & Range & $\begin{array}{c}\text { Standard } \\
\text { deviation }\end{array}$ & $\begin{array}{c}\text { Coefficient } \\
\text { of variation }\end{array}$ & Skewness & Kurtosis \\
\hline Group 1 & 22.15 & 5.88 & 1.21 & 1.11 & -0.24 \\
\hline Group 2 & 6.65 & 1.91 & 1.01 & 0.94 & -0.41 \\
\hline
\end{tabular}

correlation ( $\mathrm{r}=-0.73)$. The fitted function in Group 3 is linear (3) and its correlation is weak, but the use of a linear function fitted on this point scatter is explained by the computer technology of the 1970s.

$$
\begin{aligned}
& e_{1}=6.51\left(\text { depth }_{1}\right)^{-0.94} \\
& e_{2}=1.94\left(\text { depth }_{2}\right)^{-0.55} \\
& e_{3}=-0.006 \times \text { depth }_{3}+0.6
\end{aligned}
$$

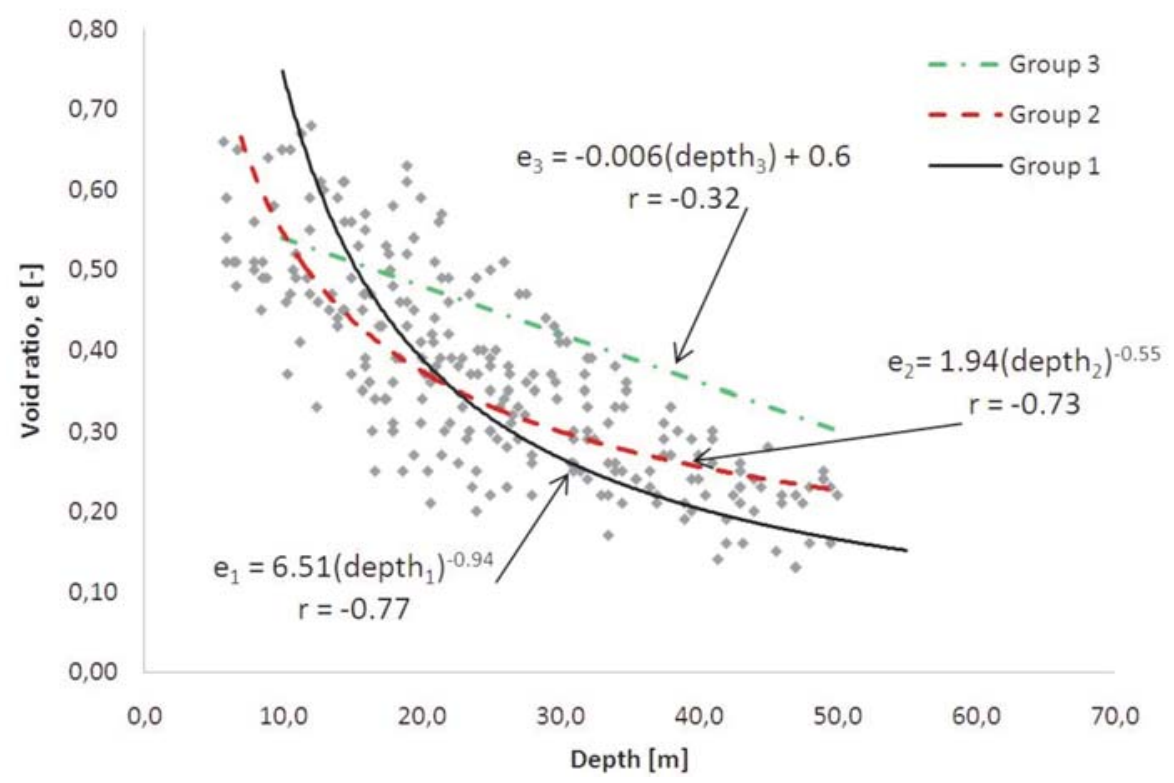

Fig. 5

Relationship between depth and void ratio 


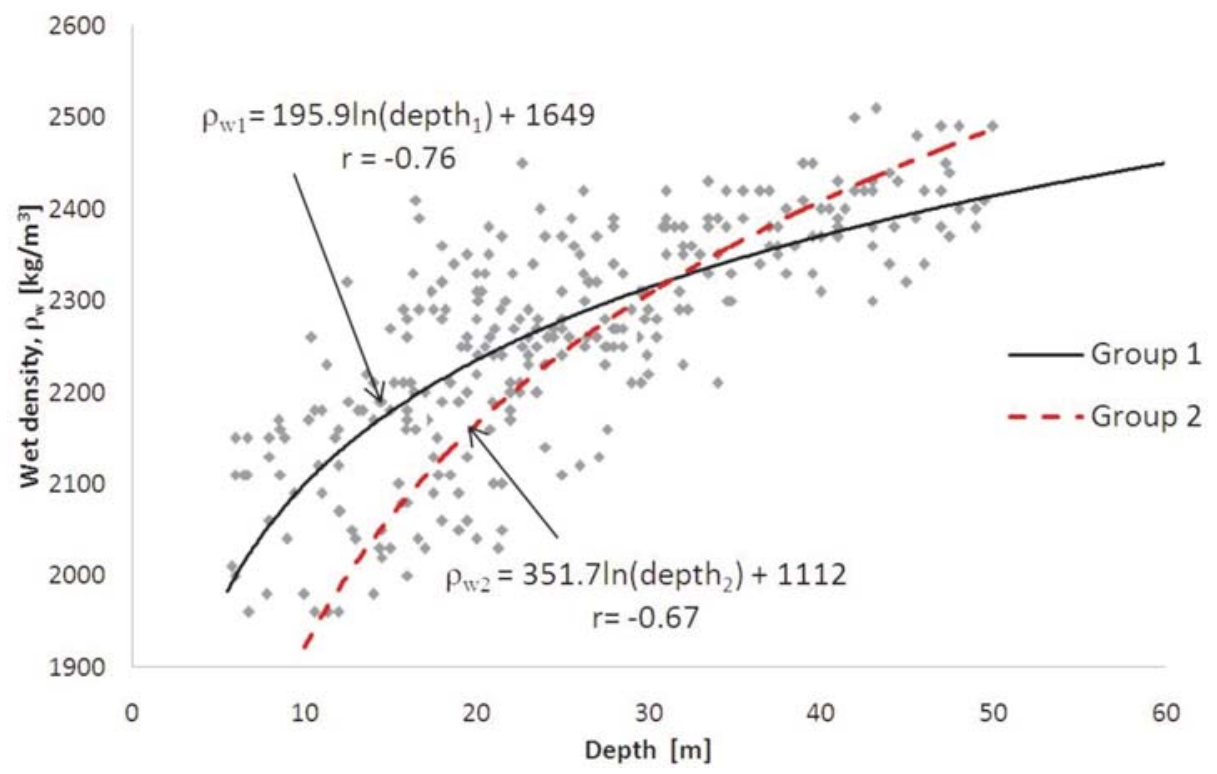

Fig. 6

Relationship between depth and wet density

Each curve shows a negative relationship because variables change in opposite directions: with increasing depth the value of void ratio decreases and the fitted function becomes steeper with increasing depth. The Kiscell Clay from Group 1 does not differ significantly from other groups.

Depth was analyzed as a function of wet density as well (Fig. 6). The relationship was described with an exponential function (4) with relatively high correlation $(\mathrm{r}=0.76)$. We can also find reference to this connection in Group 2, since its regression function was also exponential (5).

$$
\begin{aligned}
& \rho_{w 1}=195.9 \ln \left(\text { depth }_{1}\right)+1649 \\
& \rho w_{2}=351.7 \ln \left(\text { depth }_{2}\right)+1112
\end{aligned}
$$

These functions are very similar; the correlation coefficient is positive, consequently the wet density increases with depth.

Wet density values were plotted against void ratio and the relationship was described with linear functions (Fig. 7) with very high correlation. The " $r$ " value was above 0.90 in each case. The correlation coefficient is negative; thus, when the wet density is larger the void ratio is smaller. The function line of Group 2 (7) 


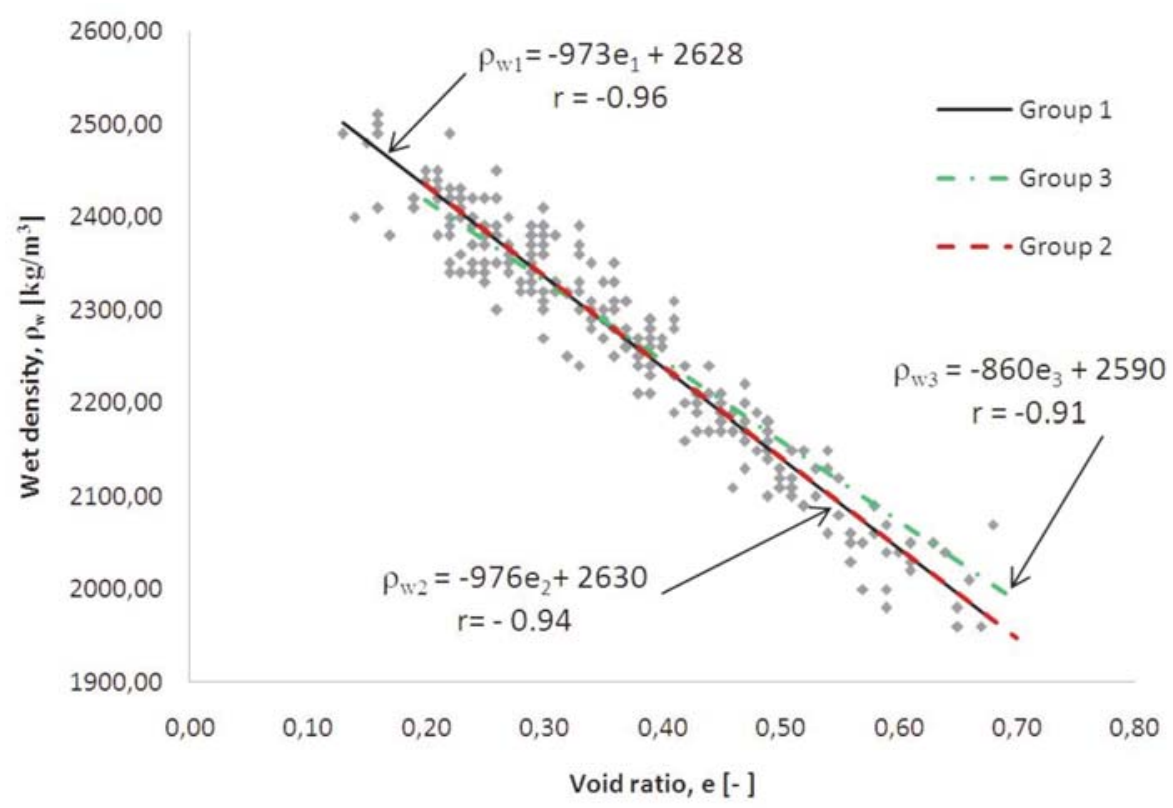

Fig. 7

Relationship between wet density and void ratio

coincides with the results of the investigations in this paper (6); the gradient of the line determined by group 3 (8) is smaller.

$$
\begin{aligned}
& \rho_{w 1}=-973 e_{1}+2628 \\
& \rho w_{2}=-976 e_{2}+2630 \\
& \rho w_{3}=-860 e_{3}+2590
\end{aligned}
$$

The relationships between densities in different states are also linear and show high correlation (Fig. 8).

The line fitted on the points of wet and dry density (9) is steeper than the function between dry and saturated (10) values, so the higher the value of dry density the closer the corresponding wet density value is to the saturated value. This is consistent with the previous relationship between density and void ratio and with high average degree of saturation of the Kiscell Clay. The lines determined by Group 2 (11-12) fitted well to data from Group 1.

$$
\begin{aligned}
& \rho_{w 1}=0.68 \rho_{\mathrm{d} 1}+873 \\
& \rho_{\mathrm{s} 1}=0.63 \rho_{\mathrm{d} 1}+1007 \\
& \rho_{\mathrm{w} 2}=0.69 \rho_{\mathrm{d} 2}+887 \\
& \rho_{\mathrm{s} 2}=0.67 \rho_{\mathrm{d} 2}+941
\end{aligned}
$$

Finally, a plasticity diagram was also plotted (Fig. 9). The connection between plasticity index and liquid limit was described with a linear equation with high 


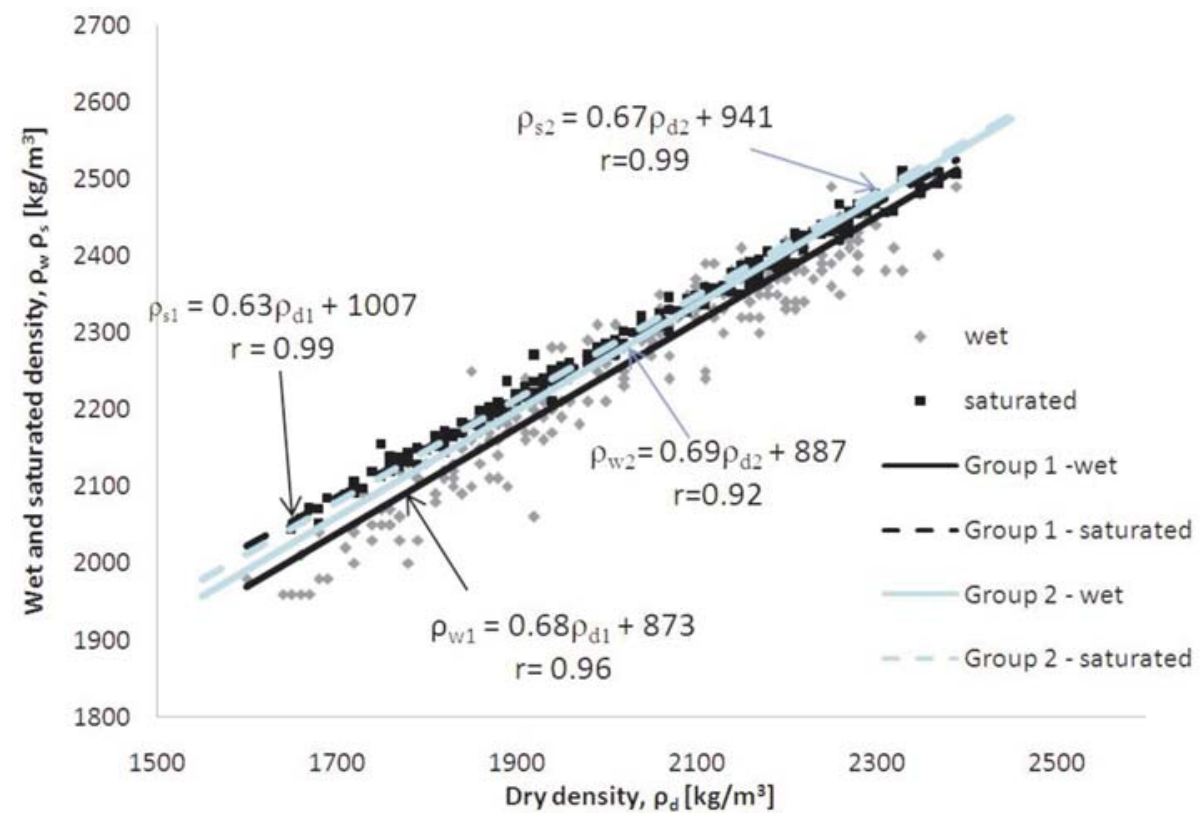

Fig. 8

Relationship between different densities

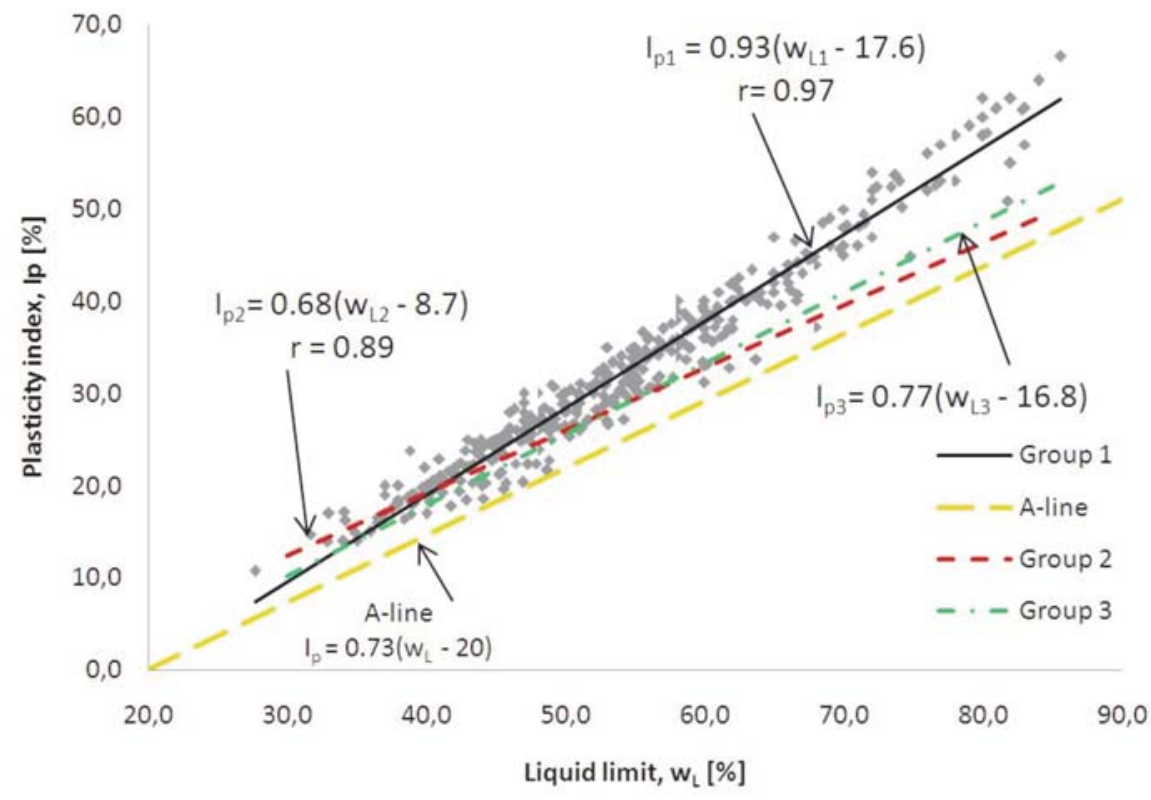

Fig. 9

Relationship between liquid limit and plasticity index

Central European Geology 55, 2012 
correlation value. Each regression curve is located above the A-line of Casagrande; therefore their origin is not organic. The lines of Groups 2 (14) and 3 (15) are almost parallel with the A-line, but the function of values from Metro Line 4 is steeper. Therefore, the increase in the plasticity index is greater than the increase of liquid limit.

$$
\begin{aligned}
& I_{p 1}=0.93\left(w_{L 1}-17.6\right) \\
& I_{p 2}=0.68\left(w_{L 2}-8.7\right) \\
& I_{p 3}=0.77\left(w_{L 3}-16.8\right)
\end{aligned}
$$

\section{Conclusions}

Over past decades several corings were carried out which evaluated the Kiscell Clay. The most extensive research was related to the design of the new Metro Line 4 , which produced a significant amount of data that had not yet been statistically analyzed. The availability of this huge data set, along with existing studies, provided the opportunity to summarize and compare results (for instance between samples from different locations).

The data analyses indicated that several properties of the Kiscell Clay are similar, independently of location. These parameters are water content, liquid limit, plasticity index, consistency index, and wet density. In each group more than half of the samples consist of fat clay, and almost all are of have hard consistency. Medians of wet density values are about $2200 \mathrm{~kg} / \mathrm{m}^{3}$. The following characteristics have high coefficient of variation and show great deviation: angle of friction, cohesion, modulus of elasticity, coefficient of compressibility, compressive strength.

A strong connection was found between the following variables and soil physical parameters: depth and void ratio, depth and wet density, wet density and void ratio, different densities, plasticity index and liquid limit. The relationships of void ratio - wet density and different densities are very similar in various groups. The plasticity diagram shows that line of Group 1 is steeper than that of the other two lines. Therefore, it is important to notice that the samples from different location cannot be unequivocally evaluated together.

\section{Acknowledgement}

The presentation of this study was supported within the framework of the "Talent Care and Cultivation in the Scientific Workshops of the BME" project, grant TÁMOP-4.2.2.B-10/1-2010-0009.

\section{References}

Barsi, I., P. Görög, Á. Török 2012: A bátaapátiból származó granitoid minták kőzetfizikai vizsgálati adatainak statisztikai értékelése (Statistical evaluation of petrophysical data of granitoid samples from Bátaapáti). - In: Török, Á., P. Görög. (Szerk.): Kőzetmechanika és kôzetkörnyezet szerepe a 
radioaktív hulladéklerakók kialakításánál (Role of rock mechanics and rock properties in the design of radioactive waste disposal sites). - Terc, Budapest, pp. 113-122. (In Hungarian.)

Görög, P. 2007a: Engineering geologic properties of the Oligocene Kiscell Clay. - Central European Geology, Acta Geologica Hungarica, 50/4, pp. 313-329.

Görög, P. 2007b: Characterization and mechanical properties of Eocene Buda Marl. - Central European Geology, Acta Geologica Hungarica, 50/3, pp. 241-258.

Horváth, Gy., B. Móczár 2011: Re-assessment of the shear strength of the Oligocene clay from the Buda area based on the site investigation of the Metro Line 4. - In: Anagnostopoulos, A. et al. (Eds): Proceedings of the 15th European conference on soil mechanics and geotechnical engineering. IOS Press, 2011, pp. 401-406.

Horváth, T., M. Fáy, Cs. Sándor 2000: A metróvonal mérnökgeológiai adottságai (Engineering geological properties of the Metro Line). - Földtani Kutatás, 37/2, pp. 35-44. (In Hungarian.)

Kárpátiné Pápay, Z., Á. Török 2007: Összefüggés a sóskúti durva mészkő tömeg-összetételi és szilárdsági tulajdonsága között (Relationship between then density and strength of coarse limestone from Sóskút). - In: XI. Nemzetközi Építéstudományi Konferencia. Csíksomlyó, Románia, pp. 91-94. (In Hungarian.)

Paál, T. 1974: Talajfizikai jellemzők eloszlás-vizsgálata (Distribution analysis of physical properties of soils). - Mélyépítéstudományi Szemle, 24/8, pp. 379-387. (In Hungarian.)

Paál, T. 1975: Regresszió analízis talajfizikai adattömegek esetén. (Regression analysis of large data sets of soil mechanical properties) - Mélyépítéstudományi Szemle, 25/1, pp. 22-30. (In Hungarian.)

Török, Á., B. Vásárhelyi 2010: The influence of fabric and water content on selected rock mechanical parameters of travertine, examples from Hungary. - Engineering Geology, 115, pp. 237-245. 